\title{
Okavango Delta - A Kalahari Oasis Under Environmental Threats
}

\author{
Michael BK Darkoh ${ }^{1^{*}}$ and Joseph E Mbaiwa ${ }^{2}$ \\ ${ }^{1}$ Department of Environmental Science, University of Botswana, Botswana \\ ${ }^{2}$ Department of Tourism Studies, University of Botswana, Botswana \\ *Corresponding author: Michael BK Darkoh, Department of Environmental Science, University of Botswana, Botswana, Tel: 3554131; E-mail: \\ darkohmb@mopipi.ub.bw
}

Received date: October 6, 2014; Accepted date: October 7, 2014; Published date: October 15, 2014

Copyright: (c) 2014, Darkoh MBK, et al. This is an open-access editorial distributed under the terms of the Creative Commons Attribution License, which permits unrestricted use, distribution, and reproduction in any medium, provided the original author and source are credited.

\begin{abstract}
Wetlands all over the world are continuously faced with enormous environmental threats. The Okavango, a Kalahari hotspot, is not an exception. This research article provides a description of the environmental threats facing the Okavango Delta, a major wetland in northern Botswana. The article is based on field evidence and synthesis of available information on the past and current state of the environment in the Delta. It is argued that the Okavango Delta has during the last few decades attracted many stakeholders with divergent interests and land use activities which together with the added impact of natural factors such as climate variability, climate change and tectonic activities in the area have slowly been transforming and causing damage to the ecosystem and its sustainability. It is emphasised that there is an urgent need to expedite the implementation of the Okavango Delta Management Plan (ODMP), if the Okavango Delta is not to end up becoming a salt pan.
\end{abstract}

Keywords: Wetlands; Environmental threats; Kalahari oasis; Hotspot; Okavango delta; ODMP

\section{Introduction}

The Okavango Delta is one of the most significant hotspots in the Kalahari Desert Region of Southern Africa. The Delta is located in Ngamiland district of Northern Botswana (Figure 1). In this wetland, water is the primary factor controlling the environment and associated life of plant and animals. This wetland has been of significant international importance since 1997 when it was declared a Ramsar site. Most recently in June this year (2014), the Delta became the 1000th UNESCO World Heritage Site.

The Delta is characterized by a conical and triangular shaped alluvial fan, with large areas of open water and grasslands. In the Delta, there are large variations in habitat patterns over small distances, although in general the Delta is flat and made up of homogeneous sand. Small differences in altitude of 1-2 $\mathrm{m}$ in the Delta represent large differences in the frequency and duration of flooding, which creates gradients from permanent rivers and lagoons, to permanent swamps with reeds and papyrus, to seasonally flooded grasslands, occasionally flooded grasslands, riverine woodlands, and dry woodlands [1]. Each of these ecosystems tends to have its distinct species composition not only of plants, but also of reptiles, birds and mammals.

Essentially an oasis in what would otherwise be a desert; the Delta is a habitat for diverse species of plants, arachnids (spiders, scorpions, ticks and mites), large herbivores and birds. Like the Nile in Egypt, the Okavango River and its Delta sustain life in an otherwise inhospitable environment. The wetland is home to a human population of about 150,000 who live within and around it and who directly or indirectly depend on the extraction of the natural resources found it [2]. As a result of its rich wildlife diversity, permanent water resources, grasslands and forests, the Okavango Delta has in the last five decades been attracting many land users with divergent land use activities such as international tourism, wildlife management, crop and livestock farming, fishing, hunting and gathering of veld products. In recent years, because of the impact of natural factors such climate change and the human activities mentioned above, this Kalahari oasis has been undergoing tremendous environmental stress, raising concerns about its future sustainability. As the threats are currently escalating, it is important that the sustainability of the Okavango Delta be made a high priority agenda item by all stakeholders with an interest in this wetland. This requires that the current Okavango Development Management Plan (ODMP) which was first launched in 2003 be given urgent priority and expeditiously implemented in order to stem this surging tide of degradation and ensure the Delta's long-term sustainability and continued provision of benefits for the present and future generations.

This research article provides a description of the environmental threats facing the Okavango Delta. The article is written by two researchers who have been carrying out extensive and sustained field research mostly on the land use and environmental aspects of the Delta for more than one and a half decades. The following methods were used to gather and analyse information for the article: firstly, personal observation through travel and field work in the Delta. In this respect must be mentioned the fact that one of the authors has been living and researching for over 10 years at the Okavango Research Institute (University of Botswana), located in the heart of Delta, which is devoted solely to research on the physical and human environment of the Delta. Second, secondary data were collected and used for the article from different published and unpublished sources, including information from the published works of the two authors.

To guide and organise the study as well as identify and describe the stresses and key environmental threats, the Drivers-Pressure-StateImpact-Response (DPSIR) conceptual framework was used [3-5]. 


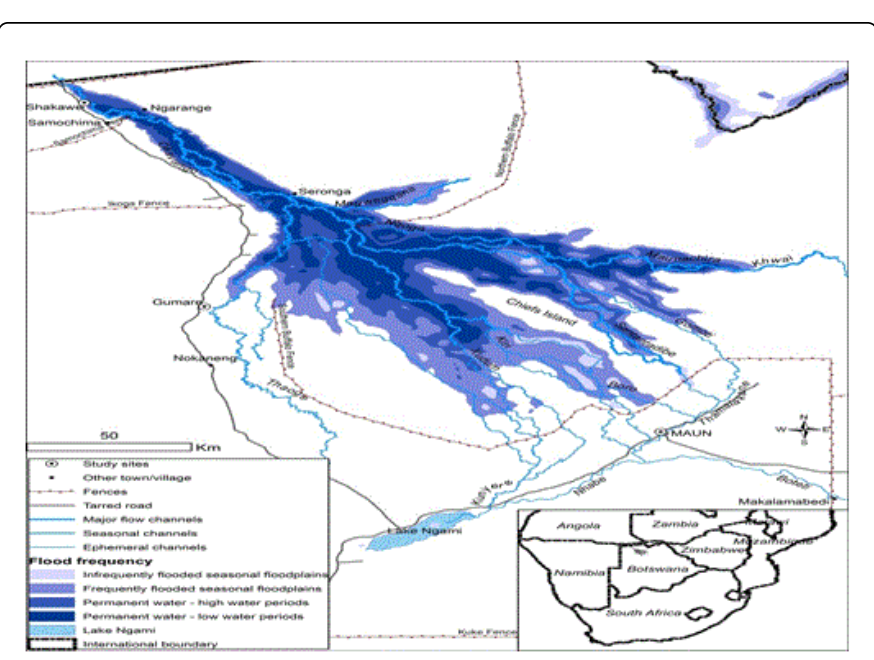

Figure 1: The okavango delta.

According to this framework, socio-economic and natural factors (driving forces) exert pressure on the environment in consequence of which the environment changes. This affects the health of the ecosystem and its dependent human population. This, in turn, may elicit a societal or government response that feeds back on all the other elements [4]. The DPSIR framework is thus a useful tool for elucidating the relationship between environment and development and tracing the origins and consequences of environmental problems in a particular ecosystem. According to UNEP [5] the framework contributes to society's enhanced understanding of the links between the environment and development, human well-being and vulnerability to environmental change.

As illustrated in Figure 2, Driving forces are natural and human factors driving environmental change. They have also been referred to as indirect or underlying drivers [5]. These are the fundamental processes in society which drive activities with a direct impact on the environment [6]. Pressures involve the stresses that human activities and natural conditions place on the environment. State refers to the condition of the environment resulting from the effects of the pressure exerted by physical and human activities on the environment. State also includes trends, which often refer to environmental change [5]. Impacts, be they on human well-being, the social and economic sectors or environmental services, are highly dependent on the characteristics of the drivers and are therefore generally location specific. Response addresses issues of vulnerability of both people and the environment and provides opportunities for reducing human vulnerability and enhancing human well-being. Responses can also be viewed as the land use policies by the government and activities by people, representing the human interventions in response to ecological and societal impacts [5].

\section{Key Environmental Stresses and Threats}

As can be gleaned from the conceptual framework outlined above, key drivers of pressures and environmental stresses emanate from two major sources, which are natural factors and human activities. In the Okavango Delta, both physical factors such as climatic variability, climate change and tectonic activities and human activities such as overgrazing of rangelands, arable farming, hunting of wild animals, over-harvesting of veld products, deforestation and bushfires are rapidly transforming the ecosystem (Table 1). These changes are in turn leading to natural resource depletion, biodiversity loss, water pollution and other forms of land degradation. Water is the principal driver of the Okavango ecosystem. The seasonal rainfall in the Angola highlands governs the extent of the annual floods in the Okavango Delta. As a result of climatic variability, the Delta is subject to seasonal pulsing, i.e. expansion and shrinking. Long-term climatic variations in flood pulse from the Okavango River create episodic wetting and drying of parts of the delta [7].

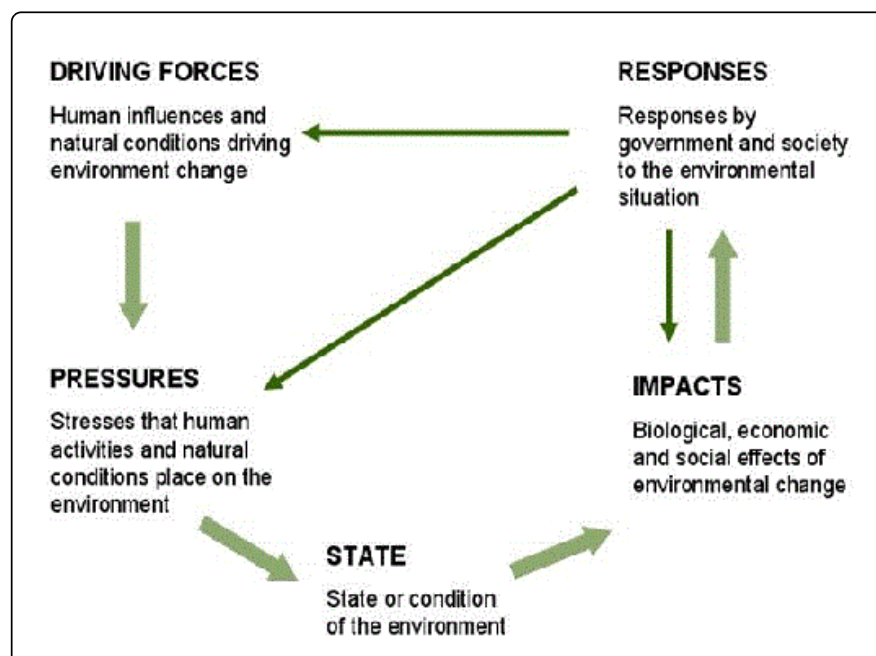

Figure 2: Drivers-Pressure-State-Impact-Response

(DPSIR) framework.

\begin{tabular}{|c|c|}
\hline Sources of Stress/Threat & Remarks \\
\hline $\begin{array}{l}\text { Climatic variability, climate } \\
\text { change and tectonic activities } \\
\text { (earthquakes) }\end{array}$ & $\begin{array}{l}\text { Natural conditions causing desiccation of } \\
\text { river channels and flooding of different parts } \\
\text { of the Okavango Delta }\end{array}$ \\
\hline Overgrazing of rangelands & $\begin{array}{l}\text { Unsustainable human activities largely } \\
\text { caused by the operations of subsistence } \\
\text { farmers under the stimulus of government } \\
\text { subsidies e.g. provision of free vaccination of } \\
\text { livestock by government. }\end{array}$ \\
\hline Arable farming & $\begin{array}{l}\text { Unsustainable human activities by } \\
\text { subsistence farmers under the stimulus of } \\
\text { subsidies from government e.g. free seeds }\end{array}$ \\
\hline Wildlife decline & $\begin{array}{l}\text { Caused by both natural factors like climatic } \\
\text { variability, climate change and diseases, and } \\
\text { human artifacts like cordon fences and } \\
\text { human malpractices like poaching and } \\
\text { burning of grassland vegetation as well as } \\
\text { unsustainable hunting and trading activities } \\
\text { in wild life products }\end{array}$ \\
\hline Over-harvesting of veld products & $\begin{array}{l}\text { Caused by human activities e.g. harvesting } \\
\text { of plants to produce baskets for commercial } \\
\text { purposes }\end{array}$ \\
\hline Deforestation & $\begin{array}{l}\text { Unsustainable subsistence livelihood } \\
\text { activities such as collection of firewood, } \\
\text { clearing land for crop production, and } \\
\text { vegetation destruction by elephants in the } \\
\text { Delta }\end{array}$ \\
\hline Bushfires & $\begin{array}{l}\text { Unsustainable practices caused by } \\
\text { subsistence farmers, tourism operators and } \\
\text { poachers }\end{array}$ \\
\hline
\end{tabular}




\begin{tabular}{|l|l|}
\hline Over Fishing & $\begin{array}{l}\text { Unsustainable fishing activities carried out for } \\
\text { both subsistence and commercial purposes }\end{array}$ \\
\hline $\begin{array}{l}\text { Uncontrollable tourism } \\
\text { development }\end{array}$ & $\begin{array}{l}\text { Unsustainable activities and practices by } \\
\text { national and foreign companies involved in } \\
\text { tourism operations }\end{array}$ \\
\hline Threats of birdlife & $\begin{array}{l}\text { Caused by climate change and } \\
\text { unsustainable human practices such as } \\
\text { poisoning of vultures by farmers and } \\
\text { poachers }\end{array}$ \\
\hline Land use conflicts & $\begin{array}{l}\text { Significant examples are those between } \\
\text { wildlife, livestock, arable land, tourism, } \\
\text { natural resource conservation and scattered } \\
\text { settlement expansions }\end{array}$ \\
\hline
\end{tabular}

Table 1: Summary of Sources of Stress/Threat in the Okavango Delta.

The Okavango Delta is subject to hydro-variability at three temporal scales: seasonal variability of rainfall, year-to-year climatic variability and multi-decadal hydrological variability [7]. Multidecadal variability has resulted in multi-decadal sequences of dry and wet conditions, leading to the Savuti Marsh, Lake Ngami, mid- and distal reaches of the Boteti River becoming dry since approximately the mid-1980s and starting to receive surface water only after 2004, with the largest flows recorded in 2010 and 2011 [7]. The Delta is also subject to channel avulsion, which is initiated by entrapment of bedload sediment within vegetation-bound channels [7]. Channel avulsion leads to large-scale redistribution of water, resulting in the desiccation of some river channels such as the Thaoge in the early 1900s, and the upper Mboroga/Jerejere in 1950s [7]. Such hydrological changes may also have possible links with global climate change but currently little work has been done to ascertain the impact of global climate change on the Delta's water inflow and ecosystem. On-going studies at the Okavango Research Institute (University of Botswana), however, suggest that global climate change is expected to have great impact on the Okavango River basin and Okavango Delta, reducing both inflows from upstream and rainfall over the Delta.

The Delta area is also tectonically active and the last major earthquake in Maun 1954 had a magnitude of 6.4 on the Richter scale [1]. At that time, most buildings were low, made of mud, reeds and grass so the damage was probably limited [1]. Now an earthquake of the same magnitude could cause major damage to the modern building structures. The impact of such seismic activities may also accelerate the river channels and flood distribution in the Delta which otherwise are moving over time scales of decades and decennia [1].

Human and animal population increase and competition for natural resources and associated land use conflicts have been primary anthropogenic factors of land disturbance and land cover change in the Delta. The most significant land use conflicts have been those between wildlife, livestock, arable land, tourism, natural resource conservation, scattered settlement expansions, as well as between subsistence use (gathering of veld products, fishing and hunting wildlife) and the need for conservation and sustainable resource utilisation $[3,8,9]$. For example, the high population of elephants (currently estimated at about 200,000 in northern Botswana) has become a major problem in the Delta as well as the Chobe enclave [10]. Elephants destroy crops and tree vegetation while lions and other animals predate on livestock.

The expansion of the cattle industry in and around the Delta has involved the erection of veterinary fences which block wildlife migratory routes in consequence of which the animals get trapped and killed, a factor, contributing to the declining wildlife populations in the Delta. Veterinary fences are a blessing and a curse in the Okavango Delta. Blessing in the sense that the Southern Buffalo fence has protected the Okavango Delta from human encroachment, hence conservation is achieved. Conversely, some of the fences have been a curse to the wetland. The ability to move within and follow areas of productivity within the delta, as well as to migrate in and out of the delta system to and from other systems like the Kwando-Linyanti, Chobe and Makgadikgadi wetland systems during extreme (wet and dry) climatic conditions, is critical to the maintenance of the delta's wildlife diversity and population numbers [11]. However, the increase in Botswana's veterinary fences has added extra barriers to some of the major wildlife movements and migration pathways [12]. The Samuchima, Ikoga and Setata fences on the western side of the Okavango and the extension of the Northern Buffalo Fence have sealed off vital wildlife habitat, terminating cross-border migrations and isolating the wildlife of the Okavango and Kwando ecosystems from their wet season dispersion range [12]. Ill-placed veterinary fences prevent vital wildlife movements, fragment populations, and impose agonizing deaths from entanglement and dehydration. Fencing infrastructure has been closely linked to the declines of Botswana's wildlife, by eroding the ability of populations to move in response to extreme climatic periods of drought or flood to seek alternative and lifesaving resources elsewhere [7]. The Namibian border cordon fence currently disrupts the spatial linkage of the Okavango Panhandle elephant population to Namibia and Angola, limiting the dispersal of elephants out of the Panhandle [13], which is causing huge pressure on a growing population and their resources in the eastern panhandle and is already being traversed by an increasing number of elephants. Within a period of two years, 26 breakages along this fence close to elephant pathway were identified [14]. Veterinary fences are erected to protect livestock from Foot-and-Mouth Diseases and in the past, the Cattle Lung Disease. They are largely meant to protect the production of beef from livestock diseases and beef exports especially to the European markets. The spread of livestock diseases and beef exports are thus creating threats to the Okavango Delta in that they facilitate the erection of veterinary fences which create barriers to wildlife migration and human movements.

Birdlife is also threatened in the Okavango Delta. The number of threats to the Okavango and Lake Ngami has increased over the years, where pressure scores have also increased on account of poisoning of birds such as vultures [7]. It has been argued that the severity of the threat from poisoning has become a serious issue, with impacts on vulture populations having been observed in the Okavango Delta [7]. The other threat is on Slaty Egrets, where the associated problems are the alteration of feeding and breeding habitat due to reduced flood levels (either natural or human-induced), fire and high densities of elephants and associated disturbance of key nesting sites. There is also a decreased prey visibility due to the alien waterweed Salvinia which is also considered as a threat. It has been noted that the potential threats faced by Wattled Cranes in Botswana come mainly from hydrological changes to floodplains that are key feeding and breeding areas for Wattled Cranes [7]. These cranes breed on sandbanks along the Okavango River panhandle, at Xigera Lagoon and along the Boro River. These are the key areas for the species and it is here also that major threats such as the disruption of breeding sites by recreational and subsistence fishermen are experienced. According to the DEA [1:74] there are eight globally threatened or near-threatened bird species in the Delta. 
Every year, the Okavango Delta undergoes uncontrolled burning of vegetation. The causes of these fires are both manmade and natural and some have been blamed on illegal hunters and the tourism industry. There is general concern that the Okavango Delta natural resources may be depleted or become scarce in the long run due to unsustainable practices. Scarcity in resources is becoming common around the villages with respect to mokola palm for basket weaving, thatching grass and river reeds. It is also emerging that pre-mature harvesting of the same resources is increasingly becoming a problem and this is further compounded by lack of harvesting permits [15]. Siltation resulting from vegetation cutting, especially papyrus and reeds, is another threat to the Okavango Delta [7]. The siltation has led to the blocking of channels and opening of other channels of the wetland. For example, the Thaoge Channel in the western part of the delta has in recent years been blocked, forcing the wetland to shift to the north-eastern direction.

Of greater concern is the increased destruction and harvesting of the Kalahari and Miombo woodland hardwood trees particularly in the northeast of the Panhandle, highlighted in a number of reports $[7,14,16]$. A combination of harvesting for poles and other construction, e.g. Mokoros (dug-out canoes) by human populations, destruction of vegetation by elephants and fire are exerting huge pressure on the riparian hardwood groves and woodlands, which hold significant ecological and cultural values. The destruction of hardwood groves and woodlands as well as other tree species has the potential of turning these hardwood areas from their present natural state into grasslands. The riparian fringes have also been disturbed by arable and livestock farming, mushrooming and encroaching non-gazetted human settlements, sand and calcrete quarrying and other development activities.

Over fishing also has been posing an imminent threat and has become a bone of contention among the three rival fishing groups in the Okavango Delta, with each user group pointing accusing fingers to other groups over the issue of perceived over fishing [3]. These groups are subsistence, commercial and sport fishers. Recreational/sport fishing operators' main concern is that commercial and subsistence fishermen are responsible for the depletion of some of the fish types in the Okavango Delta. The perceived reduction or depletion of the fish population in the area put tourist business at a risk since it depends on the availability of fish for recreation/sport activities in the area. Some of the local communities around the Okavango Delta are beginning to experience the problem of either reduced fish yields or catches of smaller sized fishes or both. These rural subsistence fishermen blame the commercial fishermen for the perceived reduction of fish population. An estimated 86 species of fish are found in the Okavango basin, 71 of which are found within the Okavango River [17,18]. While it would appear that the number of subsistence fishers have relatively declined in recent years that of commercial and sport fishers have doubled [7].

Wildlife decline is a challenge in the Okavango Delta. For example, estimated numbers of ten large mammal species in the Okavango Delta have declined severely during the past ten years. Annual rates of decline as follows: for giraffe (8\%), kudu (11\%), lechwe (7\%), tsessebe (13\%) and wildebeest (18\%) [7]. The wildebeest in Ngamiland declined from 26,000 in 1999 to 11,400 in 2010 at an annual rate of $18 \%$ [2]. Globally threatened mammals found in the Okavango Delta are the White Rhino (Ceratotherium simum), the Wild Dog (Lycaon pictus), and the Cheetah (Acinonyx jubatus) [1:74]. The level of deforestation and encroaching human activities for arable fields on the closed canopy forest islands west of Jao and Jedibe is destructive to wildlife populations [14]. The expansion of human activities into the northwest floodplains of the Okavango Delta could be affecting the area's lechwe population, whose numbers have declined by $58 \%$ compared to estimates in 1996 [14]. According to Chase, on average, wildlife decline in the Okavango Delta is $10 \%$ each year. Poaching figures in the Okavango Delta "are staggering" [8:13], and in the Wildlife Management Areas (WMAs) "the number of poachers caught on a monthly basis is relatively high" [8:13]. In NG26, which is a concession area within the Okavango Delta, a total of 33 lechwe, 21 buffalo, 19 impala, 18 giraffe, $11 \mathrm{kudu}, 4$ wildebeest, 2 hippo, 1 zebra and 204 incidents of illegal poaching activities in the past two years were reported [19]. This estimate is about $25 \%$ of the total poaching activities in the region. NG26 is one of 12 concessions bordering the buffalo fence, which suggests a conceivable 4000 animals are being harvested illegally each year [7]. Using a population model of Impala in the NG26 concession area, an additional off-take of the population, which has suffered a decline of $65 \%$ in the area from its 1996 estimate, would cause a crash in the populations of certain target ungulate species and, consequently, result in significant declines in the areas large predator populations [17]. It would seem that illegal hunting for meat may be the most significant factor accounting for the recent declines in herbivore species in northern Botswana and therefore needs to be prevented in order to maintain viable populations of targeted ungulates in the Okavango Delta [19]. While poaching is mainly for meat consumption, it ought to be noted, however, that the emerging Asian markets for products such as lion bones are also significantly encouraging poaching in the Okavango Delta [8].

The Okavango Delta is one of Africa's prime wildlife tourism destinations, and tourism has emerged as a strategic sector for generating foreign exchange, attracting foreign direct investment, creating employment and reducing poverty [7]. Approximately 120,000 tourists visit the Okavango Delta annually. However, tourism poses a threat to the environmental sustainability of the Okavango. The industry is growing and expanding in the Delta but without following proper rules and regulations as prescribed by the Okavango Delta Management Plan [1]. Moreover, regulations which apply to management of lodge sites and Controlled Hunting Areas (CHAs) such as the WMA regulations and other requirements of lease documents are not rigorously enforced [8] largely because of lack of capacity. Currently, the ecological impacts of tourism on the OD are relatively small-scale but include [20]:

- Creation of roads/tracks in protected areas (aesthetic and habitat alteration)

- Creation of airstrips (as above)

- Movement of vehicles and boats (disturbance of wildlife).

- Noise pollution (from motorized boats, light aircraft, vehicles and tourists)

- Littering and accumulation of garbage, and

- Sewerage discharge into water (contamination of surface and groundwater).

Because of the above impacts, tourism is slowly threating the wetland. Capacity limits in tourism development are being exceeded in some parts of the Delta, hence compromising environmental conservation in such areas. If tourism is not properly managed and controlled, it may exacerbate the threat to biodiversity and sustainable use of resources in the Delta. 
Invasive exotic plants and animals pose a potential disaster to the biodiversity of the Delta's ecosystem. Alien invasive species introductions are extremely hard to manage and control [8]. Salvinia molesta first appeared in the mid-1980's, but control measures conducted by the Department of Water Affairs, including the manual removal of the plant and the introduction of the Brazilian weevil beetle Cyrtobagous salviniae, which feeds on the plant, have limited the spread of the plant [7]. According to SAIEA, a variety of other alien plants, however, have appeared and are spreading through the Delta; these include jimson weeds (Datura ferox and D. stramonium), the bur weed (Xanthium starmonium), Mimosa pigra, Sesbania spp, and the exotic Syringa (Melia azederach). Some of these species cover large areas of disturbed ground and all may be doing so at the expense of the natural vegetation and the systems species diversity [7]. Invasive species like Salvinia Molesta are thus a threat to the Okavango Delta particularly as they kill all aquatic life once they populate a lagoon or river channel [7:8]. In general, it would seem that alien invasive species are slowly converting the natural habitat, out competing indigenous species and hybridizing and diluting gene pool in parts of the Delta [7].

In the 1990s, there were threats of large-scale water removal from the Okavango Delta for development programs especially mining and for water supply in the area. These threats are still present particularly now that mining prospecting around the Okavango Delta for minerals such as copper and gas has increased in the last 10 years [8]. The proposed construction of a national water project in Namibia represents the first major potential diversion of water, posing the biggest threat to the Okavango ecosystem. International interests in the use of the Okavango waters for socio-economic purposes also are causing conflict between Namibia and Botswana. Namibia has proposed two main projects which could pose direct threats to the Okavango Delta in the downstream. The first project is the large-scale water extraction project from the Kavango River to meet water demands for irrigation in Central Namibia, and urban demand in Windhoek; the second is the Hydro-electric Power Project in Popa Falls. These projects have the potential to reduce water flow and siltation in the downstream areas, hence affecting the Okavango Delta Whilst present water abstractions are "minimally significant, amounting to only $0.25 \%$ of the inflows, the potential for upstream developments such as irrigation and electricity developments in Namibia and Angola are likely to reduce the permanently flooded areas by $38 \%$ if not more" [8:26]. The extraction of water from the Okavango River and Delta is perceived by conservation NGOs, the people of Ngamiland District, the wildlife and tourist sectors as detrimental to the Okavango ecosystem, hence opposition to such projects by these groups.

\section{Conclusion}

The competition for resources and resulting unsustainable land use practices and land-use conflicts in the Okavango Delta partially reflect that the area has experienced an increased population and influx of different land users in the last few decades. Lack of land reforms and improperly coordinated land-use policies have been part and parcel of the problems facing land use and environmental sustainability in the Okavango Delta. The Okavango Delta has a history of not quite coordinated developments, with investments in infrastructure or facilities running sometimes out of sync with spatial development requirements [8:28] and conflicts in land use continuing to escalate [21]. Although attempts have been made in the past at integrated land use plans for Ngamiland such as the 1991 Land Use and Development Plan: Kwando and Okavango Wildlife Management Areas [22], these efforts have not resolved the inherent land use problems in the Delta.

The conservation and wise use of the Okavango Delta presently lies with the implementation of the the latest plan, which is the Okavango Delta Management Plan (ODMP) [1:4]. Work on this ODMP started in May 2003 and the Plan was officially launched in October 2003. The overall objective of the Plan is "to integrate resource management for the Okavango Delta that will ensure its long-term conservation and that will provide benefits for the present and future well-being of the people, through sustainable use of its natural resources" [1:5]. The Plan provides a comprehensive, integrated management strategy for the conservation and sustainable use of the Okavango Delta and surrounding areas. It aims at addressing, among other things, the following issues: conflicting and contradictory policies, humanwildlife conflicts, insufficient and inappropriate stakeholder communication and consultative mechanisms, inappropriate or unsustainable settlement development, land use practices, veterinary fences, veld fires, unsustainable harvesting of veld products, proximity of livestock to wildlife and possible over fishing [1:11]. Some of the expected output and outcomes of the ODMP Plan include the following:

- Provision of a long-term vision for the Okavango Delta that includes development options and management scenarios;

- An integrated, dynamic management plan, providing the overarching framework and contextual guidelines for all other district strategies, plans, individual area and sector plans; a plan that is adopted by all major stakeholders;

- Determination and setting levels of use in order to ensure sustainability and protection of the natural resources of the Ramsar site;

- Establishment of an institutional framework to implement the management plan.

In 2005, as a component of the ODMP, an Integrated Land Use and Land Management Plan was developed for the years 2005-2029, with the Tawana Land Board as its lead implementation agency. This plan was developed around the key stakeholders' and communities' aspirations to strengthen capacities for improved and better land use and land management practices, as well as wise and sustainable utilisation of the Delta [8].

Based on its objectives, purpose and expected outcomes, the ODMP as a whole, can be described as a positive development that has the potential to address all the problems of land utilisation and sustainable development in the Delta. Unfortunately, however, the mid-term reviews $[8,7]$ recently carried out have shown clearly that, at best, the progress in the implementation of the Plan as a whole can be described as halting. With regard to the Integrated Land Use and Land Management Plan component of the ODMP this is what one of the reviews [8] says about its progress: "The Integrated Land Use and Land Management Plan is largely unimplemented and, what is even more important, there appears to be no concerted efforts to overcome the key problems that have hampered (and continue to hamper) the plan's implementation" [8:27]. The review listed lack of stakeholders' buy-in and poor enforcement of the plan's provisions as the major impediments behind the lack of implementation. There is currently therefore an urgent need to implement this component, if the Okavango Delta is not to end up becoming a salt pan. There is also a general need to expedite the implementation of the ODMP as a whole 
as it is more than a decade since the Plan was first launched, but so far, there is little to show for its achievements in ameliorating the deteriorating environmental situation in the Delta. Meanwhile, the environmental stresses and threats in the Okavango Delta continue unabatedly.

\section{References}

1. Department of Environmental Affairs (DEA), (2008) Okavango Delta Management Plan of 2008. Department of Environmental Affairs, Ministry of Environment, Wildlife and Tourism, Government Printer, Gaborone.

2. Central Statisitics Office, CSO (2012). Population and housing Census of 2011 in Botswana. Ministry of Finance \& Development Planning, Government Printer, Gaborone.

3. Darkoh MBK, Mbaiwa JE (2005) Natural Resource Utilisation and Land Use Conflicts in the Okavango Delta, Botswana. Department of Environmental Science and Harry Oppenheimer Okavango Research Centre, University of Botswana, \& START, New York, 112 pp.

4. MacLean, M., Breeze, H., Walmsley, J. and Corkum, J. eds. 2013. State of the Scotian Shelf Report. Canadian Technical Report of Fisheries and Aquatic Sciences 3074 .

5. UNEP (2007) Global Environmental Outlook: GEO4 Environment for Development, Progress Press Ltd, Valleta, Malta.

6. Nachtergaele, F.,Biancalani, R.'Bunning, S.\& George, H. (2003) Land Degradation Assessment: the LADA approach. Accessed on 14 November 2014.

7. The Southern African Institute for Environmental Assessment, (SAIEA) (2012). Thresholds for use in the Strategic Environmental Assessment of the Okavango Ramsar Site. Unpublished Report, Maun.

8. Plantec Africa, GISPlan and Fameventures (2012) Mid-Term Review and Gap Analysis of the Okavango Delta Management Plan: Scoping and Gap Analysis Report, BTO, Gaborone, 90pp.

9. Kgathi, DL, Ngwenya B, Darkoh MBK eds. (2014) Rural Livelihoods, Risk and Political Economy of Access to Natural Resources in the Okavango Delta, Botswana. Nova Science Publishers, New York.

10. Department of Wildlife and National Parks, DWNP (2013). Department of Wildlife and National Parks Aerial Survey Report of 2013. DWNP, Gaborone Botswana.
11. Scott Wilson Resource Consultants and Environment and Development Group (2000). Environmental Impact Assessment of Veterinary fences in Ngamiland. Scot Wilson Resource Consultants and Environment and Development Group, Gaborone.

12. Albertson A (1998) Northern Botswana Veterinary Fences: Critical Ecological Impacts. Okavango People's Wildlife Trust, Maun.

13. Chase, M.J. and Griffin, C. (2009) Elephants caught in the middle: Impacts of war, fences and people on elephant distribution and abundance in the Caprivi Strip, Namibia. African Journal of Ecology, 47 (2): 223-233.

14. Chase M (2011) Fixed wing aerial survey of wildlife in the Abu wildlife management area NG26, Okavango Delta, October 2010. Unpubl. Report, Elephants Without Borders.

15. Mmopelwa GP (2005) The Value of the Okavango Delta: A Natural Resource Accounting Approach. PhD Thesis, Department of Agricultural Economics, Extension and Rural Development, University of Pretoria, Pretoria, South Africa.

16. Albertson A (2003) NG13 assessment and land use management Plan (First Draft). Shakawe, Botswana: Tcheku Community Trust, Trust for Okavango Cultural and Development Initiatives \& Bernard Van Leer Foundation, Maun.

17. Skelton PH (2001) A Complete Guide to the Freshwater Fishes of Southern Africa. Struik: Cape Town.

18. Ramberg L, Hancock P, Lindholm M, Meyer T, Ringrose S, et al. (2006) Species diversity in the Okavango Delta, Botswana. Aquatic Sciences 68: 310-337.

19. McNutt JW (2012) Modeling the impact of illegal bushmeat hunting in Botswana. Unpublished Paper, 9pp.

20. Mbaiwa JE (2003) The Socio-Economic and Environmental Impacts of Tourism in the Okavango Delta, Northwestern Botswana. Journal of Arid Environments, 54 (2): 447-468.

21. Darkoh MBK \& Mbaiwa JE (2009) Land Use and Resource Conflicts in the Okavango Delta, Botswana. African Journal of Ecology, 47(Suppl.1), 161-165.

22. Van der Haiden LJ (1991). Land use and Development Plan: Kwando and Okavango Wildlife Management Areas. DLUPU-Ngamiland District, Maun. 